\title{
Gastric Cancer Pathologic Primary Tumor TNM Finding v8
}

National Cancer Institute

\section{Source}

National Cancer Institute. Gastric Cancer Pathologic Primary Tumor TNM Finding v8. NCI Thesaurus. Code C133605.

A pathologic finding about one or more characteristics of gastric cancer, following the rules of the TNM AJCC V8 classification system as they pertain to staging of the primary tumor. 